\title{
Effects of Shadow Banking on Return - Empirical Study Based on Chinese Commercial Banks
}

\author{
Jingyu Tang ${ }^{1} \&$ Yanling Wang ${ }^{2}$ \\ ${ }^{1}$ Bank of Shanghai, Shanghai, China \\ ${ }^{2}$ SILC Business School, Shanghai University, Shanghai, China \\ Correspondence: Yanling Wang, Lecturer, Deputy Dean of Accounting Department, SILC Business School, Shanghai \\ University, Shanghai, China. \\ Received: December 27, 2015 \\ Accepted: January 13, 2016 \\ Online Published: January 19, 2016 \\ doi:10.5430/ijfr.v7n1p207 \\ URL: http://dx.doi.org/10.5430/ijfr.v7n1p207
}

\begin{abstract}
We study the effect of shadow banking, proxied by the share of net fees and commissions income to total revenue on the return and risk-adjusted return of Chinese commercial banks. We find that as banks tilt their product away from traditional lending business and toward fee-based business, or shadow banking business, its level of earning increase. In addition, the relation of shadow banking business and the risk-adjusted return, denoted by sharp ratio, is positive. Besides, we also discover that the variables we select, such as shadow banking ratio, capital adequacy ratio has more crucial impacts on risk-adjusted return than on ROAA. Together, our empirical evidence is broadly consistent with the notion that shadow banking is associated with higher return and risk of commercial banks.
\end{abstract}

Keywords: shadow banking, commercial bank, return

\section{Introduction}

The 2007 global financial crisis revealed the enormous destructive power of shadow banking system. Since then on shadow banking has gain more and more attention across the world. In July 2010, Dodd-Frank Act, the strictest financial reforming act since 1930, was approved. However, according to Nov, 2014 report from Financial Stability Board the volume of global shadow banking has reached the 75 trillion US dollars since the financial crisis, and the potential risks may threaten the stability of financial system. US government has promulgated Reform of financial institutions, rehabilitation and Enforcement Act (1989) and Federal Deposit Insurance Corporation Improvement Act (1991), but resulted in financial institutions developed outside the regulations. It was the Financial Modernization Act in 1990 and Commodity Futures Modernization Act in 2000 that repeal the Bank Law in 1933 and lead to the rapid growth of shadow banking. After financial crisis, U.S. President Barack Obama signed the Dodd-Frank Wall Street Reform and Consumer Protection Act to strictly regulate shadow banking.

Recent research on shadow banking enriches. However, scholars reach controversial conclusions on whether shadow banking business improve return or risk-adjusted return. Some argue that shadow banking, as a form of financial innovation, improve return of financial institute via reducing transaction costs (Schwarcz, 2012; Duffie and Jackson, 1990; Ross, 1988; Boot and Thakor, 1997), information asymmetry, and regulation arbitrage. Besides, we refer to diversification theory and investment portfolio theory raised by Markowitz, the risk diversification benefit is determined by the risk, or volatility and the correlation of each asset. So the relation of return and risk-adjusted return for banks and shadow banking business could be positive, negative and even a U shape. Furthermore, Calmes and Theoret (2011) found endogeneity amplifies banks' risk-return trade-off.

It is fortunate that Chinese financial system suffered a little from the global financial crisis. Shadow banking business in China is composed of loan origination organizations, like trust firms, leasing firms, and off-balance-sheet business of commercial banks, like entrusted loans, and is believed remain mostly in banking system (Ba, 2008) since securitization and derivatives are not prevalent yet. According to Moody's report, Chinese shadow banking has reached 41 trillion in the end of 2014, accounts for $65 \%$ of the GDP. So it is crucial to study the effects of shadow banking business on Chinese commercial banks. Reviewing literature on banks, we discover that some scholars has studied share of noninterest income of commercial banks to test the influence of shadow banking on return, but they also reached inconsistent conclusions (Huang, 2011; Wei, Ni, \& Fu, 2010; et al.). Another challenge lies in measurement of shadow banking business. Most previous study denote shadow banking income as noninterest income of commercial bank (Calmes and Theoret, 2011; Huang, 2011). A closer investigation on annual reports of 
Chinese commercial banks reveals that fee-based income, a component of noninterest income is a better measurement of shadow banking business.

Therefore, we apply empirical study to investigate the relation between shadow banking and return of commercial bank. Banking industry is highly regulated in China, so there are only limited number of banks whose information disclosure is enough for us to constitute our data set. Our sample is composed of annual fiscal data from 43 Chinese commercial banks during 2007 to 2011 because China Banking Regulatory Commission announced in 2012 that Chinese commercial banks' wealth-management products, the major shadow banking products are taken into regulation. Furthermore, we consider share of shadow banking business income as well as variables proxying for banks attributes, bank operation quality and asset quality. Based on diversification theory, financial innovation theory, investment portfolio theory, we raise the hypotheses and models. Our evidence indicates that running more shadow banking business, return on average asset tend to be higher. We also find that risk-adjusted return, measured by sharp ratio, appears to be positively related to share of shadow banking business income. One plausible explanations for the results is that according to risk diversification theory and investment portfolio theory raised by Markowitz, the correlation of shadow banking and traditional loan business effective to diversify risk while improving return. In addition, Chinese scholar Ba (2012) share the view that shadow banking is essentially financial innovation, which essentially gain more return through information asymmetry and bypassing regulation. In addition, Innovation could also attract more strategic clients since their demands are more complex and thus more profitable. Finally, we find evidence that the higher shadow banking business income, the more return and risk-adjusted return a Chinese commercial bank will gain.

Every coin has two sides, study on risk management of running shadow banking business is left blank in our research. Existing literature reveals that in aggregate level of banking system, shadow banking distort the credit system (Meeks et al. 2012) and bring about new challenge to the existing regulation. In individual level of each bank, rather than the higher risk-adjusted return, which may be tempting in the short term, innovation is actually the essence of shadow banking for Chinese commercial banks in the long term, because they are now left with no choice but to keep and continue innovation facing with new competition from online-business and direct finance institutions.

This paper proceeds as follows. Section 2 discuss about prior study on shadow banking. Section 3 develops the hypothesis, sample and methodology. Section 4 presents results, followed by additional analysis in section 5 . The final section provides conclusions.

\section{Literature Review and Hypothesis Development}

\subsection{Prior Reasearch on Shadow Banking}

Shadow banking included financial firms, asset backed commercial papers conduits, limited purpose financial firms, structured investment institutions, credit hedge funds, security lenders and government sponsored firms. It keeps the following traits. First, according to Financial Stability Board and Financial Crisis Inquiry Commission, it is unregulated or lightly regulated by traditional regulatory system, and it didn't gain guarantees from central bank or public institutions. Second, shadow banking conduct traditional banking functions and transfer traditional credit relations into securitized credit relations (Adrian and Ashcraft ,2012; Gennaioli et al. ,2011; Metrick , 2010) Third, it is an institution that conversed maturity, credit and liquidity without guarantees from central bank or public institutions (Pozar, Adrian et al., 2010). We agree with Ba (2013) on that Chinese shadow banking was essentially financial innovation and diversification. He also pointed out that greater risks remained in the traditional macro-financial structure, while diversification actually improved efficiency of financial economy.

Meeks et al. (2012) found that shadow banking actively taking risk resulted in expansion of credit and converted the maturity of traditional banks, and in turn the credit supply could be more sensitive. Sunderam (2012) proved that shadow banking could satisfy money demand by issuing short-term notes, which equals money creations, and money demand stimulated growth of asset-backed commercial paper market. US data from 1984 to 2011 showed that the time traditional banking credit crunch from 1990 to 2007 was the period when shadow banking credit expensed (Meeks et al. 2012). Geithner pointed out that shadow banking not only underestimated market risks, but also significantly strengthened the linkages in global market.

Many scholars argue that shadow banking, as a form of financial innovation, improve the return of financial institute via reducing transaction costs (Schwarcz, 2012; Duffie and Jackson, 1990; Ross, 1988; Boot and Thakor, 1997). The reasons could be: 1) Shadow banking cause information asymmetry by amplifying complexity or making products and financial transactions more difficult to disclose and understand. Iwaisako (2010) put that due to information asymmetry, it gained more profits than traditional banks, which fueled its expansion. 2) Regulatory arbitrage means financial engineering that use the difference within regulatory position and economic substance to evade unwelcome regulation. FSB has addressed the importance of supervision and regulation on shadow banking system where regulatory arbitrage and systemic risk maintains. however, extensive literature held that it was not free to enjoy the 
benefits brought about by the shadow banking, since it decreased banks' capabilities of filtering loans and monitoring risks, so as to negatively impact banks important functions as liquidity providers (Rajan, Seru and Vig, 2010; Piskorski, Seru and Vig, 2009; Parlour and Plantin, 2008).

According to Investment portfolio theory by US economist Markowitz, volatility represented risks of wealth-management products, and was measured by standard deviation or variance. Scholars have also studied diversifications on geography, loan portfolio, deposits, and non-banking activities, and tested the risk-adjusted return while reaching vague conclusions: on one hand, Santomero and Chun (1992), Saunders and Walter (1994), Chiorazzo, Milani and Salvini (2008), Calmes and Theret (2012) et al. suggested that diversification is associated with lower risk and higher return. Kwan (1998) put that the commercial banks can enjoy diversification benefits because of low return correlation between bank subsidiaries and securities. Calmes and Theoret (2011) used Canadian dataset to conduct empirical study and found that shadow banking could increase risk-return trade-off, which was underestimated without considering endogeneity. On the other hand, Stiroh (2006) suggested that noninterest income can be more risky, and didn't generate higher average equity returns. Demsetz and Strahan (1997) argued that the diversification benefits are off-set by larger C\&I loans and lower capital ratio. It is quite interesting that Hayden, Porath, and Wsternhagen (2007) even discovered a U shape relation between diversification and risk-adjusted return.

If we move forward to studies on commercial bank about diversification and noninterest income, conclusions still appear to be controversy. Smith et al. (2003) studies European bank system and found that noninterest income stabilized revenues for banks and generate diversification benefits. Chiorazzo (2008) proved that noninterest income was positively related to adjusted risks by adopting Italian dataset. Other scholars doubted these results. Stiroh (2004) conducted empirical research to discuss aggravate risk as well as individual risk. He argued that the declining volatility of net operating revenue is due to reduced volatility of net interest income instead of diversification benefits caused by noninterest income. DeYong and Roland (2001) thought fee income amplified income volatility without diversification benefits. Acharya et al. (2002) studies Italian banks and found bank asset (loan portfolios) failed to diversify the risks or improve performance. Stiroh and Rumble (2006) thought diversification benefits were mitigated by volatility risks. DeYong and Rice (2004), and Baele (2007) held noninterest income increased banks profitability as well as income volatility.

To sum up, it appears to be plausible that shadow banking business within commercial banks generate premium return through information asymmetry and regulation arbitrage. However, diversification effects are uncertain and determined by the following factors: 1) risk, or volatility, and return of running fee-based business. 2) The correlation of traditional lending business and fee-based business. 3) Banks features and regulation system, for example its size, capital adequacy ratio, location and so on.

\subsection{Research on Shadow Banking in China}

Ba (2009) pointed out that shadow banking extended credit chain by credit expansion, leading to irrational exuberance and ultimately resulted in subprime crisis. Yi (2009) pointed out that shadow bank expanded credit via financial innovation, generating instability inherent in financial market. Yi (2009) pointed out that shadow bank expanded credit via financial innovation, generating instability inherent in financial market. Adopting investment portfolio theory, Huang (2011) conducted empirical research and found that shadow banking, represented by commercial bank wealth-management products, amplified fund cost to commercial banks as well as risks to the whole financial system. Besides, Zhang and $\mathrm{Li}$ (2010) conducted empirical research to found that noninterest income showed little impact on domestic banks return or risks. Zhou and Wang (2008), Huang (2011) utilized investment portfolio theory to prove that noninterest income produce more risks than net interest income.

In all, most Chinese research on shadow banking was theoretical analysis focused on the operating mechanism and regulating measures while empirical research was rare.

\subsection{Hypothesis Development}

Extensive literature on commercial banking showed that increase in banks non-traditional activities could significant impact banks risk-return trade-off, but in different directions. (De Yong and Roland, 2001; Estrella, 2001; Acharya et al., 2002; Strioh, 2004; Stiroh and Rumble, 2006; Baele et al., 2007; De Jonghe, 2009; Nijshens and Wangner, 2011). Risk can be hedged if two assets are not completely correlated according to investment portfolio theory. However, due to different regulation system in each country, degree of business mix in banks varies. Sharp ratio, named after William F. Sharpe, indicates the risk-adjusted return, and can be regarded as the robustness of impacts on return on average asset. It measures the excess return per unit of deviation.

Regarding to financial innovation theory, shadow banking, as a form of financial innovation, may decrease transaction costs and taxes so as to increase return. Due to information asymmetry between the fund providers and 
banks, shadow banking can conduct adverse selection to maximize it return. Secondly, shadow banking keeps lower capital requirements and loss provisions, so the asset utilization efficiency can be improved to generate higher return. Thirdly, according to financial innovation, shadow banking can get access to more fund resources by transferring illiquid asset to liquid asset and in turn bring about more profits for the banks. Last but not least, regulatory arbitrage pulses shadow banking's return. Shadow banking can flexibly bypass these regulations so as to get access to more loan resources and improve the profit for commercial banks. In sum, by conducting more shadow banking business, Chinese commercial banks enjoy higher risk-adjusted return.

Hypothesis 1: shadow banking activities within Chinese commercial banks is positively related to bank return (ROAA).

Hypothesis 2: shadow banking activities within Chinese commercial banks is positively related to sharp ratio, the risk-adjusted return.

\section{Method}

\subsection{Sample Selection}

Since commercial bank wealth-management products, regarded as shadow banking products, were first issued in 2004 in China, this market grew rapidly in 2007 and almost reach its peak in 2012. In 2013 Chinese commercial bank industry has undergo essential changes, given rise to not only the external environment-financial markets integration, internet financial organization emerges and so forth-but also legislative and regulatory innovations. China Banking Regulatory Commission took commercial banks' wealth management products and the related off-balance-sheet business under regulation in 2012. So our sample are constructed of fiscal data from 2007 to 2011.

Banking industry is highly concentrated in China with the top 5 banks accounts for more than $40 \%$. Besides the listed 16 banks, we selected a total 43 banks who disclose information enough for us to construct the sample. Because some banks fail to disclose enough information in certain year while they are very important to our research, like Agriculture Bank of China, they are still included in our sample with data of some years missing. In addition, we scattered the sample and deducted some extreme data. So our sample is finally unbalanced panel data, as shown in the following table. We also conducted GLS regression to test the robustness of the results. Bank data are derived are from annual reports and Bankscope, a comprehensive data set for bank study, and processed by Excel and Stata 11.

\subsection{Dependent Variavle}

\subsubsection{Return on Average Asset}

The indexes used to reflect profitability includes: return on average asset (ROAA) and return on average equity (ROAE). Scholars believe that ROAA measures the profitability of the total asset, so it can be regarded as a long-term index. However, ROAE mainly shows the current profitability of the bank equity in the specific fiscal year. So in our study, consistent with many previous literatures (Calmes and Theoret, 2011; Wei, Ni, and Fu, 2010), we choose ROAA reported by Bankscope and the annual reports to reflect bank return.

\subsubsection{Sharp Ratio}

There are three standard ways to measure risk: 1) the standard deviation of the return on average assets under ongoing operational assumption, 2) insolvency risk measures or probability of failure of a given bank, denoted by Z-score (Note 1), 3) the ratio of loan loss provision to net loans. In this paper, we use the first method, the standard deviation of return on average assets (ROAA) to measure risk because the focus of our study is the volatility of ROAA.

Referring to Lepetit et al. (2008), $\sigma_{\mathrm{t}, \mathrm{ROAA}}$ the standard deviation of ROAA, is represented by a moving standard deviation competed on a rolling window of three years. The volatility is regarded as risk in investment portfolio theory. So the variable is expressed as:

$$
R I S K_{t}=\sqrt{\sum_{t=1}^{i+2}\left(R O A A_{i}-\overline{R O A A)^{2}}\right.}
$$

According to investment portfolio theory, Sharp $\mathrm{t}_{t}=\frac{\mathrm{ROAA}_{\mathrm{t}}-\overline{\mathrm{ROAA}}}{\sigma_{\mathrm{t}, \mathrm{ROAA}}}$, where $\sigma_{\mathrm{t}, \mathrm{ROAA}}$ is the volatility derived by the moving average calculated by a rolling window of three years, and $\overline{\mathrm{ROAA}}$ is the mean value of ROAA over the whole sample period.

$$
\operatorname{Sharp}_{t}=\frac{R^{2} A A_{t}-\overline{R O A A}}{\sqrt{\sum_{t=1}^{i+2}\left(R O A A_{i}-\overline{R O A A}\right)^{2}}}
$$




\subsection{Testable Variable}

\section{Shadow banking ratio}

In Chinese context, the revenue of shadow banking business remain within Fees \& Commissions in the fiscal report. We denote shadow banking ratio as the percentage of net fees and commissions revenue dividing total revenue. Reasons are:1) according to the review of those employee in Chinese banks, almost all the nontraditional business are off-balance-sheet business and reflected in fees \& commissions income. 2) Referring to some reports from securities firms (Note 2), all the sub-items of fees and commissions were related to shadow banking, even those sound like traditional commercial banking business, such as bank card (Note 3). Besides, most of the sub-item business is interrelated. 3) As we mentioned above, many existing literature simply denote shadow banking income as noninterest income of commercial bank (Calmes and Theoret, 2011; Huang, 2011). However, in China, shadow banking ratio proxied by the percentage of net fees and commissions revenue on total revenue is much more accurate compared with the previous studies. So the variables are defined as:

\section{Shadow Banking Ratio $=$ Net Fees and commissions/Total Revenue}

\subsection{Control Variable}

Based on previous study on banks, we construct the following control variables. (1) Bank Characters. Scholars fail to reach joint agreement on how level of bank asset size relates to return. Some argue that level of bank asset size is inversely correlated to bank return (Chiorazzo, Milani\& Salvini, 2008, et. al), while others put that size may be not related to ROAA significantly (Huang, 2012; Shih et al., 2007; Lin and Zhang, 2009). Chinese commercial banks are unique for the biggest four banks are SOEs and smaller banks behave more flexible to earn higher profits. So we assume that level of bank size is negatively related to return as well as risk-adjusted return. (2) Bank Operation Quality. Cost-to-Income Ratio measures the cost control capability of banks, so it is inversely related to return and risk-adjusted return. Net Interest Margin reflects the profitability level of banks and in turn is positively related to the dependent variables. (3) Asset quality. Capital Adequacy Ratio, Loan loss Provision and Non-Performing Loan reflects the asset quality of a bank. So it is obvious that the better asset quality, the higher ROAA should be. So capital adequacy ratio is positively related to ROAA while non-performing loan is negatively related to ROAA.

Table 1. Variable description

\begin{tabular}{|c|c|c|c|}
\hline Type & Variables & Symbols & Descriptions \\
\hline $\begin{array}{l}\text { Independent } \\
\text { Variable }\end{array}$ & Shadow Banking Ratio & SB & $\begin{array}{l}\mathrm{SB}=\mathrm{Net} \text { Fees and commissions/ Total } \\
\text { Revenue }\end{array}$ \\
\hline \multirow{3}{*}{$\begin{array}{l}\text { Dependent } \\
\text { Variable }\end{array}$} & $\begin{array}{l}\text { Return on Average } \\
\text { Asset }\end{array}$ & ROAA & Net Income/Average Total Asset \\
\hline & \multirow{2}{*}{ Sharp Ratio } & \multirow{2}{*}{ Sharp } & $R O A A_{i}-\overline{R O A A}$ \\
\hline & & & $\sqrt{\sum_{t=1}^{i+2}\left(R O A A_{i}-\overline{R O A A)^{2}}\right.}$ \\
\hline \multirow{7}{*}{$\begin{array}{l}\text { Control } \\
\text { Variable }\end{array}$} & Loan Loss Provision & LLP & Loan Loss Provision/Net Interest Revenue \\
\hline & Non-performing Loan & NPL & Nonperforming Loans/Total Loans \\
\hline & Capital Adequacy Ratio & CAR & Capital/Risk Weight Asset \\
\hline & & & (Business management fee + other operating \\
\hline & Cost-to-Income Ratio & $\mathrm{CI}$ & $\begin{array}{l}\text { expenses }) /(\text { Net interest income }+ \text { net fee } \\
\text { income }+ \text { other operating income }+ \\
\text { investment income })\end{array}$ \\
\hline & Net Interest Margin & NIM & Net Interest Income/Earning Asset \\
\hline & Banks Size & Size & In(Total Asset) \\
\hline
\end{tabular}




\section{Aggression Model:}

$$
\begin{aligned}
& \operatorname{ROAA}_{i, t}=\alpha_{0}+\beta_{1} S B_{i, t}+\beta_{2} C A R_{i, t}+\beta_{3} C I_{i, t}+\beta_{4} N P L_{i, t}+\beta_{5} N I M_{i, t}+\beta_{6} L L P_{i, t}+\beta_{7} \operatorname{Size}_{i, t}+\epsilon \\
& \operatorname{Sharp}_{i, t}=\alpha_{0}+\beta_{1} S B_{i, t}+\beta_{2} C A R_{i, t}+\beta_{3} C I_{i, t}+\beta_{4} N P L_{i, t}+\beta_{5} N I M_{i, t}+\beta_{6} L L P_{i, t}+\beta_{7} \operatorname{Size}_{i, t}+\epsilon
\end{aligned}
$$

\section{Results}

\subsection{Descriptive Data and Correlation Analysis}

Table 2 shows the descriptive analysis for this study and demonstrates the features of the sample. The sample is balanced panel data. There are totally 215 variable observes from 2007 to 2011. Because Sharp ratio is calculated by the moving average method of 3 years, we lost 86 observations. Shadow banking business income, accounts for an average of $7.62 \%$ of the total revenue, with the highest of $34.9 \%$ and the lowest of $0.27 \%$. The average percentage of fees and commissions income lags behind its peer banks in the US: For example, the noninterest income of JP Morgan accounts for 38\% of the total revenue in 2011. Banking industry is profitable in China even during the global financial crisis period with average ROAA around $1.04 \%$. Level of cost control is varies dramatic across banking industry, shows the different cost control capability. The average capital adequacy ratio is $12.31 \%$, higher than the required $8 \%$. However, the lowest capital adequacy ratio is only $4.47 \%$, so a portion of Chinese commercial banks may face some risks. The asset quality of Chinese commercial banks needs improving in the future. Loan loss provisions

Table 2. Descriptive statistics

\begin{tabular}{cccccc}
\hline Variable & Obs & Mean & Std. Deviation & Min & Max \\
\hline ROAA (\%) & 215 & 1.044 & 0.359 & 0.015 & 2.13 \\
\hline Sharp & 129 & -0.2049 & 2.069 & -10.842 & 6.374 \\
\hline SB (\%) & 215 & 7.619 & 5.447 & 0.279 & 34.923 \\
\hline Size & 215 & 5.328 & 0.821 & 3.856 & 7.190 \\
\hline CI (\%) & 215 & 36.877 & 7.630 & 22.050 & 67.483 \\
\hline NIM (\%) & 215 & 2.899 & 0.869 & -0.130 & 6.5 \\
\hline CAR (\%) & 215 & 12.301 & 3.134 & 4.470 & 30.14 \\
\hline NPL(\%) & 215 & 1.762 & 2.751 & 0 & 23.75 \\
\hline LLP (\%) & 215 & 14.439 & 10.635 & -3.240 & 78.91 \\
\hline
\end{tabular}

Table 3 shows the correlation between the independent (SB) and the dependent variables (ROAA and sharp). The results of correlation table indicates that $\mathrm{SB}$ is positively related to risk-adjusted return and return which is statistically significant $(\mathrm{p}<0.05)$. We listed correlation of other variables in the appendix.

Table 3. Correlation between SB, ROAA and Sharp

\begin{tabular}{llll}
\hline & ROAA & Sharp & SB \\
\hline ROAA & 1 & & \\
\hline Sharp & $0.5776^{* * *}$ & 1 & \\
\hline SB & $0.1481^{*}$ & 0.0695 & 1 \\
\hline
\end{tabular}

$* * *, * *$ and $*$ indicate significance, respectively, at the $0.1 \%, 1 \%$ and $5 \%$ levels.

\subsection{Multivariate Regression Analysis}

Some literature analysis showed that ROAA model is influenced by endogeneity (Stiroh, 2004; Baele et al., 2007; Stiroh and Rumble, 2006; Huang and Zhang, 2012). Banks return on average asset can be a function of share of shadow banking while share of shadow banking business may be a function of ROAA. So we substitute SB with the first-order lag-term and the second order lag-term to test the robustness of our regression. In addition, some scholars 
argue that level of bank asset size is inversely correlated to bank return (Chiorazzo, Milani\& Salvini, 2008, et. al), while others put that size may be not related to ROAA significantly (Huang, 2012; Shih et al., 2007; Lin and Zhang, 2009). Demsetz \& Strahan (1997) discovered that larger banks are more diversified. So we conducted stepwise regression to take care of heteroscedasticity problem. In order to test the robustness of the regression, we conducted GLS regression at the same time, which successfully proved our hypothesis. The regressions for ROAA are applying with STATA 11.

Table 4. Regression estimates for ROAA Model

\begin{tabular}{|c|c|c|c|c|c|c|}
\hline Model & $\begin{array}{c}\text { Predicted } \\
\text { Sign } \\
\end{array}$ & $\mathrm{I}$ & II & III & IV & $\begin{array}{c}\text { GLS } \\
\text { Regression }\end{array}$ \\
\hline$S B$ & + & & $\begin{array}{c}0.0226^{* * *} \\
(5.55)\end{array}$ & & & $\begin{array}{c}0.2333^{* * *} \\
(5.61)\end{array}$ \\
\hline SBt-1 & + & & & $\begin{array}{c}0.0251^{* * *} \\
(5.65)\end{array}$ & & \\
\hline SBt-2 & + & & & & $\begin{array}{c}0.02155^{* * *} \\
\quad(4.86)\end{array}$ & \\
\hline SIZE & - & $\begin{array}{c}-0.0143 \\
(-0.75)\end{array}$ & $\begin{array}{c}-0.1333^{* * *} \\
(-4.78)\end{array}$ & $\begin{array}{c}-0.1526^{* * *} \\
(-4.82)\end{array}$ & $\begin{array}{c}-0.1180^{* * *} \\
(-3.43)\end{array}$ & $\begin{array}{c}-0.1321^{* * *} \\
(-4.81)\end{array}$ \\
\hline$C A R$ & + & $\begin{array}{l}0.0089 \\
(1.91)\end{array}$ & $\begin{array}{c}0.0089^{*} \\
(2.05)\end{array}$ & $\begin{array}{l}0.0072 \\
(1.11)\end{array}$ & $\begin{array}{c}-0.0024 \\
(-0.28)\end{array}$ & $\begin{array}{c}0.00996^{*} \\
(1.03)\end{array}$ \\
\hline$C I$ & - & $\begin{array}{c}-0.0263^{* * *} \\
(-13.31)\end{array}$ & $\begin{array}{c}-0.0279^{* * *} \\
(-14.93)\end{array}$ & $\begin{array}{c}-0.0305^{* * *} \\
(-13.83)\end{array}$ & $\begin{array}{c}-0.0291^{* * *} \\
(-11.74)\end{array}$ & $\begin{array}{c}-0.279^{* * *} \\
(-15.04)\end{array}$ \\
\hline$L L P$ & - & $\begin{array}{c}-0.0158^{* * *} \\
(-11.23)\end{array}$ & $\begin{array}{c}-0.0153^{* * *} \\
(-11.60)\end{array}$ & $\begin{array}{c}-0.0161^{* * *} \\
(-9.84)\end{array}$ & $\begin{array}{c}-0.01557^{* * *} \\
(-7.69)\end{array}$ & $\begin{array}{c}-0.0152^{* * *} \\
(-10.69)\end{array}$ \\
\hline NIM & + & $\begin{array}{c}0.1375^{* * *} \\
(7.74)\end{array}$ & $\begin{array}{c}0.1263^{* * *} \\
(7.56)\end{array}$ & $\begin{array}{c}0.1244^{* * *} \\
(6.03)\end{array}$ & $\begin{array}{c}0.1628^{* * *} \\
(6.28)\end{array}$ & $\begin{array}{c}0.1280^{* * *} \\
(6.48)\end{array}$ \\
\hline$N P L$ & - & $\begin{array}{c}-0.0225^{* * *} \\
(-4.06)\end{array}$ & $\begin{array}{c}-0.0235^{* * *} \\
(-4.55)\end{array}$ & $\begin{array}{c}-0.0156^{*} \\
(-1.69)\end{array}$ & $\begin{array}{c}-0.01147 \\
(-1.26)\end{array}$ & $\begin{array}{c}-0.026^{* * *} \\
(-3.19)\end{array}$ \\
\hline Constant & & $\begin{array}{c}1.8485^{* * *} \\
(10.54)\end{array}$ & $\begin{array}{c}2.396^{* * *} \\
(12.54)\end{array}$ & $\begin{array}{c}2.645^{* * *} \\
(10.67)\end{array}$ & $\begin{array}{c}2.443^{* * *} \\
(8.4)\end{array}$ & $\begin{array}{c}2.372^{* * *} \\
(11.66)\end{array}$ \\
\hline $\begin{array}{c}\text { Adjusted } \\
\qquad R^{2}\end{array}$ & & 0.6392 & 0.6858 & 0.672 & 0.7054 & 0.7111 \\
\hline $\mathbf{N}$ & & 215 & 215 & 172 & 129 & 215 \\
\hline $\mathbf{P}$ & & 0.0000 & 0.0000 & 0.0000 & 0.0000 & 0.0000 \\
\hline
\end{tabular}

$t$ statistics in parentheses

$* * *, * *$ and $*$ indicate significance, respectively, at the $0.1 \%, 1 \%$ and $5 \%$ levels.

According to Table 4, shadow banking ratio and its lag terms are all significantly related to ROAA which is tested under $99 \%$ significant in fixed effects regression. Besides, the independent variable is still significant under $99 \%$ significant level without controlling level of bank size. We also run GLS regression to test whether our result is robust. In sum, we safely reach the conclusion that the more shadow banking business done by Chinese commercial banks, the higher their return are. Other variables effects are consistent with our assumptions that better asset quality (CAR, LLP and NPL) the bank owns, and the more profitable (NIM and CI), the higher ROAA appears to be. 
Investment portfolio theory suggests that sharp ratio measures the return of taking unit risk. Table 5 shows the mean Sharp ratio of the sample in the year 2009 to 2011. Referring to Lepetit et al (2008), we denote volatility as a moving standard deviation competed on a rolling window of three years, and then derive sharp ratio of each banks while losing 86 observers. According to table 5, due to the 2007 financial crisis, the risk-adjusted return of Chinese commercial banks declines to negative in 2009, and then rocket in 2010 because of the QE of Chinese central bank.

Table 5. Mean sharp ratio of each banks

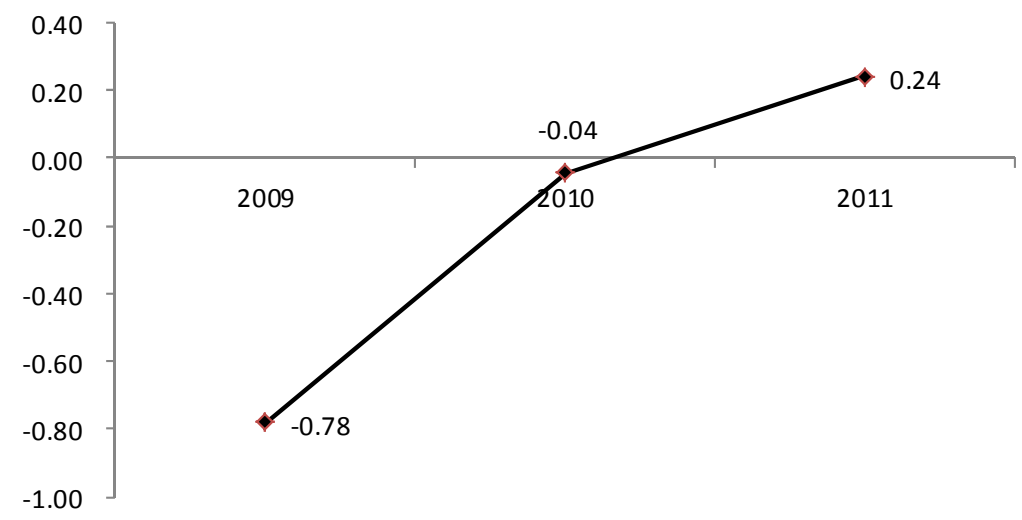

Table 6. Regression estimations for Sharp Model

\begin{tabular}{|c|c|c|c|c|}
\hline Model & Predicted sign & I & II & GLS Regression \\
\hline$\overline{S B}$ & + & & $\begin{array}{c}0.185^{* * *} \\
(3.57)\end{array}$ & $\begin{array}{c}0.1736^{* * *} \\
(3.63)\end{array}$ \\
\hline SIZE & - & $\begin{array}{c}-0.00141 \\
(-0.01)\end{array}$ & $\begin{array}{l}-1.003^{* *} \\
(-2.82)\end{array}$ & $\begin{array}{c}-0.9766^{* *} \\
(-2.74)\end{array}$ \\
\hline CAR & + & $\begin{array}{c}0.25773^{* *} \\
(3.10)\end{array}$ & $\begin{array}{c}0.253^{* *} \\
(3.20)\end{array}$ & $\begin{array}{c}0.2370^{*} \\
(2.21)\end{array}$ \\
\hline$C I$ & - & $\begin{array}{c}-0.101^{* * *} \\
(-4.21)\end{array}$ & $\begin{array}{c}-0.1181^{* * *} \\
(-5.05)\end{array}$ & $\begin{array}{c}-0.1119^{* * *} \\
(-4.40)\end{array}$ \\
\hline$L L P$ & - & $\begin{array}{c}-0.08334^{* * *} \\
(-4.18)\end{array}$ & $\begin{array}{c}-0.0774^{* * *} \\
(-4.06)\end{array}$ & $\begin{array}{c}-0.0770^{* *} \\
(-3.12)\end{array}$ \\
\hline NIM & $?$ & $\begin{array}{c}0.5759^{*} \\
(2.29)\end{array}$ & $\begin{array}{c}0.5081^{*} \\
(2.12)\end{array}$ & $\begin{array}{c}0.5124^{*} \\
(2.33)\end{array}$ \\
\hline$N P L$ & - & $\begin{array}{c}-0.00462 \\
(0.05)\end{array}$ & $\begin{array}{l}-0.207 \\
(0.24)\end{array}$ & $\begin{array}{l}0.0111 \\
(0.82)\end{array}$ \\
\hline Constant & & $\begin{array}{c}-0.2306 \\
(-0.09)\end{array}$ & $\begin{array}{l}4.439 \\
(1.64)\end{array}$ & $\begin{array}{l}4.359 \\
(1.61)\end{array}$ \\
\hline $\mathbf{N}$ & & 126 & 126 & 126 \\
\hline Adjusted $R^{2}$ & & 0.284 & 0.349 & 0.3788 \\
\hline $\mathbf{P}$ & & 0.0000 & 0.0000 & 0.0000 \\
\hline
\end{tabular}

$t$ statistics in parentheses

$* * *, * *$ and $*$ indicate significance, respectively, at the $0.1 \%, 1 \%$ and $5 \%$ levels. 
According to Table 6, shadow banking ratio is positively related to sharp ratio of commercial banks at $99 \%$ significant level, while the stepwise regression indicates that adding the independent variable SB significantly improve the adjusted R square of Sharp model, so our hypothesis that shadow banking business positively related to sharp ratio is proved. The regression analysis for Sharp model is applying with software STATA 11. All the VIFs are smaller than 5 , so regression is not affected by multicollinearity.

Other results are consistent with our expectation: CAR and NIM is positively related to sharp ratio, and LLP and CI are negatively related to sharp ratio. The coefficients of NIM are the largest in the regression model. It is interesting that coefficients of almost all variables appears to be much higher in sharp model than that in ROAA model, so we guess that the variables have much more crucial impacts on risk-adjusted return than ROAA.

\section{Additional Analysis}

This paper considers the percentage of fees $\&$ commissions income as shadow banking ratio to test its influence of return and risk-adjusted return. Other reasons also lead the same conclusions. (1) Literature has shown that the shadow banking can bring about the potential benefit of diversifying risk (McAllister and McManus, 1993; Santomero and Chung, 1992; Saunders and Walter, 1994). A plausible explanation is that correlation of shadow banking and traditional loan business effective to diversify risk while improving return. (2) Chinese scholar Ba (2012) share the view that shadow banking is essentially financial innovation, and the traditional commercial banking business may maintain higher risk than shadow banking. So the operation volatility can be even less running shadow banking business to individual banks. Besides, innovation could bring about more benefits to banks, for example, attracting more strategic clients since their demands are more complex and thus more profitable, enjoying more tax benefits, and avoiding some non-necessary regulations. (3) In practice, traditional credit department will take in the loss, which is quite minor, from shadow banking business in case of the bad debt. Non-interest income business plays an important role in Chinese commercial banks. So they would switch the loss of shadow banking business into traditional business. These reasons could possibly be reflected in the premium return of higher ROAA and risk-adjusted return.

Relatively limited observations of our data set may undermine conclusions of this research. Almost all banks in China are SOEs, so there are limited number of banks while information disclosure is not sufficient enough to build the data set before the year 2007. In 2012, Chinese banking regulation commission announced that wealth management products from commercial banks, which are blamed to be widely expanding, are regulated from then on. However, the major investment of wealth management products-real estate and government financing platform- still thirsty of fund. Thus shadow banking business remains within commercial bank system, but the formation keeps changing to meet the requirement of regulation. Besides, endogeneity problem exists since some unobservable variables can also influence the return and risk-adjusted return. Demsetz \& Strahan (1997) discovered that larger banks are more diversified, while the largest banks in China are all SOEs and the medium sized banks are controlled by local governments. Many scholars and practicers find that banks controlled by local government or private sectors run shadow banking business more aggressively. In other words, ownership of banks may influence behavior of banks, and in turn impact return. So the change of regulations landscaped and institutional environment have impacts on shadow banking ratio of commercial banks. Further study can compare the impacts of regulation changes effects on shadow banking business, as well as dig out the undiscovered variables to solve the endogenous problem.

\section{Summary}

\subsection{Conclusions}

The underlying assumption of our research is diversification theory, financial innovation theory, investment portfolio theory, we raise the hypotheses and models. This research takes the share of net fees and commissions income to total revenue as a proxy for shadow banking business within Chinese commercial banking system, as well as considering banks attributes, bank operation quality and asset quality. Our sample is composed of annual fiscal data from 43 Chinese commercial banks during 2007 to 2011 because regulation modified in 2012. Conclusions are consistent with many scholars that by running more shadow banking business, return and risk-adjusted return of Chinese commercial banks tend to be higher. Besides, we also discover that the variables we select, such as shadow banking ratio, capital adequacy ratio has more crucial impacts on risk-adjusted return than ROAA. Results are statistically significant.

In additional analysis, other explanations also lead to similar results, from which we infer that the correlation of shadow banking business and traditional loan business effectively diversify risk. Running shadow banking business by bypassing regulation successfully improve profit and efficient, which result in attracting more clients. Therefore, 
shadow banking business links to more return and risk-adjusted return.

However, it's better to hesitate before aggressively expand into shadow banking business, since it may cause trouble to risk management. In aggregate level of banking business, shadow banking business distort the credit system and bring about new challenge to the existing regulation system. In individual level of each banks, rather than the higher risk-adjusted return, which may be tempting in short term, innovation is actually the essence of shadow banking for Chinese commercial banks, who are blamed to be quite conservative to some extent. Nowadays, Chinese banking industry is faced with challenges from online-business and direct finance which bypass bank system to finance from equity market or online finance institutions. Chinese banking industry is left with no choice but to keep and continue it innovation, such as expanding to securitization, fee-based business.

\subsection{Limitations and Research Suggestions}

This research studies the relation of shadow banking business with return of Chinese commercial banks. Although we use fee-based income as proxy for shadow banking business, which is more accurate than non-interest income, there still remain a gap between the measurement in this research and the truth volume of shadow banking within bank system.

It is widely agreed that essence of shadow banking is credit creation (Yi, 2009; Zhen, 2009; et al.) outside of the bank system, however arguments of shadow banking definition and its influence varies a lot. In the future study, it is rewarding to continue monitoring and studying shadow banking business in China. New rule from China Banking Regulatory Commission in 2012 took wealth management product, which is thought to be a typical shadow banking product, into regulatory context, however, financial organizations still try to bypass regulation. So future study could focus on the influence of regulation change.

\section{References}

Acharya, V. V., H. Iftekhar, \& A. Saunders. (2002). The Effects of Focus and Diversification on Bank Risk and Return: Evidence from Individual Bank Loan Portfolio.CEPR Discussion Ppaer No.3252.

Adrian, T., \& A. B. Ashcraft. (2012). Shadow Banking Regulation. Ssrn Electronic Journal, 4(4), 99-140.

Adrian, T., \& H. S. Shin. (2009). The Shadow Banking System: Implications for Financial Regulation. Ssrn Electronic Journal. http://dx.doi.org/10.2139/ssrn.1441324

Akhavein, Jalal D., Allen N. Berger, \& David B. Humphrey. (1997). The Effects of Megamergers on Efficiency and Prices: Evidence from a bank Profit Function. Finance \& Economics Discussion 12(1), 95-139. http://dx.doi.org/10.1023/A:1007760924829

Baele, L., O. DeJonghe, \& R.V. Vennet. (2007). Does the Stock Market Value Bank Diversification. Journal of Banking and Finance, 31, 1999-2023. http://dx.doi.org/10.2139/ssrn.883593

Berger, A. N., I. Hasan, \& M. Zhou. (2010). The effects of Focus Versus Diversification on Bank Performance: Evidence from Chinese Banks. Journal of Banking and Finance, 34, 1417-1435. http://dx.doi.org/10.1016/j.jbankfin.2010.01.010

Boot, A., \& A. Thakor. (1997). Banking scope and financial innovation. Review of Financial Studies, 10(4), 1099-1131.

Boyd, J. H., \& M. Gertler. (1994). The Role of Large Banks in the Recent US Banking Crsis. Federal Reserve Bank of Minneapolis Quarterly, 18.

Calmes, C., \& R. Theoret. (2011). The Rise of Shadow Banking and the Hidden Benefit of Diversification. Working Paper, Département des sciences administratives, UQO.

Canals, J. (1993). Competitive Strategies in European Banking. Oxford University Press: Oxford.

Chiorazzo, V., C. Milani, \& F. Sal. (2008). Income Diversification and Bank Performance: Evidence from Italian Banks. Journal of Financial Services Research, 33, 181-203. http://dx.doi.org/10.1007/s10693-008-0029-4

De Jonghe, O. (2010). Back to the Basics in Banking? A Micro-analysis of Banking System Stability. Journal of Financial Intermediation, 19(3), 387-417. http://dx.doi.org/10.1016/j.jfi.2009.04.001

Demsetz, R. Z., \& Strahan, P. E. (1997). Diversification, Size and Risk at Bank Holding Companies. Journal of Money, Credit, and Banking, 29(3), 300-3134.

DeYoung, R., \& K. P. Roland. (2001). Product Mix and Earnings Volatility at Commercial Banks: Evidence from a Degree of Total Leverage Model. Journal of Financial Intermediation, 10(1), 54-84. 
http://dx.doi.org/10.1006/jfin.2000.0305

DeYong, R., \& T. Rice. (2004). Non-interest Income and Financial Performance at U.S. Commercial Banks. The Financial Review, 39, 101-127.

Duffie, D., \& M. O. Jackson. (1989). Optimal innovation of futures contracts. Review of Financial Studies, 2, 275-296.

Estrella, A. (2001). Mixing and Matching: Prospective Financial Sector Mergers and Market Valuation. Journal of Banking and Finance, 25, 2367-2392. http://dx.doi.org/10.1016/S0378-4266(01)00195-9

Gallo, J. G., Apilado, V. P., \& Kolari, J. W. (1996). Commercial bank mutual fund activities: Implications for bank risk and profitability. Journal of Banking and Finance, 20, 1775-1791.

Gennaioli, N., A. Sheifer, \& R. W. Vinshny. (2011). A Model of Shadow Banking. Journal of Finance, 68(4). http://dx.doi.org/10.2139/ssrn.2133418

Ghosh, S., I. G. del Mazo, \& İ. Ötker-Robe. (2012). Chasing the Shadow: How Significant Is Shadow Banking in Emerging Markets?. The World Bank, Economic Premis.

Gorton, G., \& A. Metrick. (2010). Regulating the Shadow Banking System. Social Science Electronic Publishing, 41(2), 261-312. http://dx.doi.org/10.2139/ssrn.1676947

Hayden, E., D. Porath, \& N. v. Westernhagen. (2007). Does Diversification Improve the Performance of German Banks? Evidence from Individual Bank Loan Portfolios. Journal of Financial Service Research, 32, 123-140.

Iwaisako, T. (2010). Global Financial Crisis, Hedge Funds, and the Shadow Banking System. Policy Research Insititute, Ministry of Finance, Japan, Public Review, 6(3), 347-368.

Lepetit, L., E. Nys et al. (2008). Bank Income Structure and Risk: An Empirical Analysis of European Banks. Journal of Banking and Finance, 32, 1452-1467. http://dx.doi.org/10.1016/j.jbankfin.2007.12.002

Loutskina, E. (2011). The Role of Securitization in Bank Liquidity and Funding Management. Journal of Financial Economy, 100(3), 663-684. http://dx.doi.org/10.1016/j.jfineco.2011.02.005

Loutskina, E., \& P. Strahan. (2010). Informed and Uninformed Investment in Housing: The Downside of Diversification. Review of Financil Studies, 24(5), 1447-1480. http://dx.doi.org/10.1093/rfs/hhq142

Meeks, R., B. Nelson, \& P. Alessandri. (2014). Shadow banks and Macroeconomic instability. Ssrn Electronic Journal. http://dx.doi.org/10.2139/ssrn.2405394

Miller, M. H. (1986). Financial innovation: The last twenty years and the next. Journal of Financial and Quantitative Analysis, 21(4), 459-471. http://dx.doi.org/10.2307/2330693

Myers, S. C., \& N. S. Majluf. (1984). Corporate financing and investment decisions when firms have information that investors do not have. Journal of Financial Economics, 13(2), 187-221.

Nersisyan, Y., \& L. R. Wray. (2010). The Global Financial Crisis and the Shift to Shadow Banking. Levy Economics Institute. http://dx.doi.org/10.2139/ssrn.1559383

Nijskens, R., \& W. Wagner. (2011). Credit Risk Transfer Activities and Systemic Risk: How Banks Became Less Risky Individually But Posed Great Risks to the Financial System at the Same Time. Journal of Banking and Finance, 35, 1391-1398. http://dx.doi.org/10.1016/j.jbankfin.2010.10.001

Parlour, C., \& Guillaume Plantin. (2008). Loan sales and Relationship Banking. Journal of Finance, 63, 1291-1314.

Piskorski, T., A. Seru, \& V. Vig. (2010). Securitization and Distressed Loan Negotiation: Evidence from the Subprime Mortgage Crisis. Journal of Financial Economics, 97(3), 369-397.

Rajan, U., A. Seru, \& V. Vig. (2015). The failure of models that predict failure: Distance, incentives and default. Journal of Financial Economics, 115(2), 237-260. http://dx.doi.org/10.1016/j.jfineco.2014.09.012

Ross, S. A. (1989). Institutional markets, financial marketing and financial innovation. Journal of Finance, 43(3), 541-556.

Saunders, A., \& Walters. (1996). Universal Banking in the United States. Politics.

Schwarcz, S. L. (2012). Regulating Shadow Banking. Review of Banking and Financial Law, 31. http://dx.doi.org/10.2139/ssrn.1993185

Smith, R., C. Staikouras, \& G. Wood. (2003). Non-interest Income and Total Income Stability. Social Sciences Electronic Publishing. 
Stein, C. J. (2010). Securitization, Shadow Banking, and Financial Fragility. Daedalus, 139(4), 41-51.

Stiroh, K. J. (2004). Diversification in Banking: Is Noninterest Income the Answer?. Journal of Money, Credit and Banking, 36(5), 853-882.

Stiroh, K. J. (2006). A Portfolio View of Banking with Interest and Noninterest Activities. Journal of Money, Credit and Banking, 38(5), 1351-1361.

Stiroh, K. J. (2006). New Evidence on the Determinants of Bank Risk. Journal of Financial Service Reserve, 30 , 237-263. http://dx.doi.org/10.1007/s10693-006-0418-5

Stiroh, K. J., \& A. Rumble. (2006). The Dark Side of Diversification: The Case of US Financial Holding Companies. Journal of Banking and Finance, 30(8), 2131-2161. http://dx.doi.org/10.1016/j.jbankfin.2005.04.030

Sunderam, A. (2014). Money Creation and Shadow Banking System. Review of Financial Studies, 28(4), 939-977.

Tufano, P. (1989). Financial Innovation and first-mover advantages. Journal of Financila Economics, 25(2), 213-240.

Van, D. P. (2010). Shadow Banking and the Financial Crisis. Regulation, 33(2), 61.

Wei, S., Ni, N., \& Fu, Z. (2010). The Relationship between Non-Interest Income and the Performance of the Bank Empirical Analysis of 40 banks in China. Future and Development, (2).

Zhang, K. (2012). Shadow Banking: Opportunity and Challenge to Commercial Banks. Journal of New Finance, (4), 35-39.

Zhang, Y., \& Li, L. (2010). Can Noninterest Income Reduce Bank Risk? Evidence from Chinese Banking Industry. NanKai Economics Studies, (4), 69-91.

Zhou, L. (2012). Research on the Progress, Deficiency and Solution of the International Regulation on Shadow Banking System. Studies of International Finance, (1), 43-53.

Zhou, W., \& Wang, J. (2008). A Review of the Fluctuation of Non-interest Income of the Commercial Banks of Our Country from the Perspective of Portfolio Theory. Economic Survey 2008a, (4).

\section{Notes}

Note 1. The common equation is expressed as: $\mathrm{Z}-$ score $=\frac{\text { capital }- \text { asset ratio }+\mu_{R O A}}{\sigma_{R O A}}$

Note 2. In the Dec 27, 2012 report on Shadow Banking from Chinese Merchants Securities, the settlement and clearing business in commercial banks could be partly classified as shadow banking.

Note 3. According to 2011 annual report of China Construction Bank, private bank card and wealth management card, which provide financial innovation products and wealth-management products, is becoming popular.

Appendix 1. Correlation matrix

$(\mathrm{obs}=215)$

\begin{tabular}{|c|c|c|c|c|c|c|c|c|c|}
\hline & Sharp & ROAA & SB & Size & CAR & $\mathrm{CI}$ & LLP & NIM & NPL \\
\hline Sharp & 1 & & & & & & & & \\
\hline ROAA & $0.5776 * * *$ & 1 & & & & & & & \\
\hline SB & 0.0695 & $0.1481^{*}$ & 1 & & & & & & \\
\hline Size & -0.0811 & 0.0208 & $0.7861^{* * *}$ & 1 & & & & & \\
\hline CAR & $0.2819^{* *}$ & $0.2236^{* * *}$ & -0.0599 & -0.0937 & 1 & & & & \\
\hline $\mathrm{CI}$ & $-0.4029^{* * *}$ & $-0.5745^{* * *}$ & 0.0174 & -0.0723 & -0.0845 & 1 & & & \\
\hline LLP & $-0.2908^{* * *}$ & $-0.3915^{* * *}$ & $-0.2182 * *$ & $-0.21^{* *}$ & -0.0609 & -0.0749 & 1 & & \\
\hline NIM & $0.2875^{* * *}$ & $0.3324 * * *$ & $-0.1870^{* *}$ & $-0.3064 * * *$ & 0.0759 & $-0.1374 *$ & $0.1538^{*}$ & 1 & \\
\hline NPL & 0.0127 & $-0.1805^{* *}$ & -0.0281 & -0.0396 & $-0.1467^{*}$ & -0.0433 & 0.0684 & $0.1133^{*}$ & 1 \\
\hline
\end{tabular}

$t$ statistics in parentheses

$* * *, * *$ and $*$ indicate significance, respectively, at the $0.1 \%, 1 \%$ and $5 \%$ levels. 